\title{
SUSTAINING PRECARIOUS TRANSNATIONAL FAMILIES: THE SIGNIFICANCE OF REMITTANCES FROM CANADA'S SEASONAL AGRICULTURAL WORKERS PROGRAM
}

Don Wells

Professor,

School of Labour Studies and

Department of Political Science,

McMaster University,

Hamilton, Ontario, Canada

wellsd@mcmaster.ca

André Lyn

Manager,

Community Investment,

United Way of Peel Region,

Mississauga, Ontario, Canada

alyn@unitedwaypeel.org

\author{
Janet McLaughlin \\ Assistant Professor, \\ Department of Health Studies, \\ Wilfred Laurier University, \\ Waterloo, Ontario, Canada \\ jmclaughlin@wlu.ca
Aaraón Díaz Mendiburo
Professor,
School of Social Work,
Universidad Autónoma del Estado
de Morelos,
Temixco, Morelos, Mexico \\ faraondiaz@yahoo.com.mx
}

\begin{abstract}
Accelerating flows of remittances are dwarfing global development aid. This study deepens our understanding of remittance impacts on the families of workers who come to Canada annually for several months under the Seasonal Agricultural Workers Program (SAWP). Interviews with SAWP workers, their spouses, adult children and teachers in Mexico deepen our understanding of the impacts of these remittances. They demonstrate that the remittances are often literally a lifeline to transnational family survival, allowing them to pay for basic needs such as shelter, food, and medical care. Yet, at the same time, the raemittances do not allow most of these workers and their families to escape deep poverty and significant precarity, including new forms of precarity generated by the SAWP. Instead, SAWP remittances help reduce poverty, at least temporarily, to more moderate levels while precarious poverty expands through global neoliberal underdevelopment.
\end{abstract}

\footnotetext{
Oome 200 million workers around the world are working for wages 7 outside of their countries of citizenship (Crowley and Hickman 2008). In 1 Canada, over 300,000 temporary foreign workers (TFWs) labour under
} 
programs set up by the federal government that are expanding rapidly in an increasingly diverse range of sectors. The agricultural sector has special importance, in particular the Seasonal Agricultural Workers Program (SAWP), in which workers from Mexico and the Caribbean have been migrating to Canada for nearly half a century. ${ }^{1}$

As a response to grower pressures (McLaughlin 2010: 82), in 1966 the SAWP began recruiting workers from Jamaica, followed by workers from other Commonwealth Caribbean states and Mexico (Satzewich 1991). Since 1966 135,000 migrant agricultural workers have come to Canada under the SAWP (Hennebry and Preibisch 2012: 32). Currently about 27,000 come to Canada annually, with more than 15,000 of them going to southern Ontario where they do half the horticultural work in the province (Binford 2013: 44, 196). Under this program, impoverished, racialized workers from historically colonized countries come to Canada for six weeks to eight months annually before they are required to return home. This circular labour migration is a pattern of repetitive family fragmentation and reunification embedded in selection processes designed to preclude permanent settlement by recruiting those who are married and/or have children (Basok 2000a: 224). Most return to Canada year after year, sometimes for more than 20 years. $^{2}$

Remittances from Canada are a significant annual flow of income to SAWP families in Mexico, Jamaica and other Caribbean countries. In recent years, SAWP remittances to Mexico have increased from CAD \$152.7 million in 2010 to CAD $\$ 174.1$ million in 2012. The average remittance per worker (CAD \$9,879.32 per worker in 2012) has remained about the same in these years, as has the ratio of average remittances to net earnings in Canada, which was 76.8 percent in 2012. ${ }^{3}$ Guanajuato, the state on which research for this article is based, received CAD $\$ 12.3$ million, or $\$ 10,717$ per worker (STyPS n.d., a). Similar data are not available for Jamaican workers, but the Jamaican Ministry of Labour has tracked the amount remitted through a mandatory savings program in which all workers must remit 16 percent of their income through mandatory deductions. In 2012, this amounted to CAD \$16.1 million, or an average of $\$ 2,557$ per worker (Jamaica Ministry of Labour and Social Security 2013). This figure does not capture remittances sent directly by workers to their families.

According to UN estimates, 500 million people, 8 percent of the global population, receive remittances (Castles and Miller 2009: 59). At triple the levels of official development aid flows, and exceeding private debt and portfolio equity flows to countries in the global South, officially recorded remittance flows to developing countries are growing at 8 percent a year and are estimated to reach $\$ 414$ billion USD in 2013, with actual flows considered "significantly larger" by the World Bank. ${ }^{4}$ Remittances are particularly important in Mexico, which is the fourth largest recipient ( $\$ 22$ billion) in the world. At over $\$ 2$ billion USD and 14 percent of its GDP, Jamaica's remittances equal the total revenues of its largest industry, tourism, are nine times its total inflows of foreign direct investment, and 
exceed its total exports and foreign exchange reserves. ${ }^{5}$ These figures are impressive. Yet scholars debate how much remittances are contributing to more diversified, sustainable economic development relative to simply reinforcing ongoing dependency at low income levels (Kapur 2004; Nyberg-Sørensen et al. 2002; Lopez-Cordova and Olmedo 2007; Massey and Parrado 1998).

Despite the recognized importance of remittances at a macro level, few studies have examined the use of remittances among SAWP workers, especially from a qualitative perspective. Most conclude remittances are mainly used for expenses such as buying land and homes; household appliances and repairs; debt payments; feeding, clothing and educating children; and medical expenses. Less often, but more likely among long-term participants, remittances are used for small productive ventures, such as investing in small businesses (Basok 2000b; Binford 2013; Hennebry 2006). ${ }^{6}$ Little has been written about Jamaican remittances, although McLaughlin (2009a, 2009b) found similar uses to those of Mexican SAWP participants.

About 95 percent of SAWP participants report having children (Hennebry et al., forthcoming), and almost all have dependents (such as elderly parents). Opportunities to earn wages and transform them into family remittances constitute most SAWP workers' primary, indeed almost sole motivation for sojourning in Canada. Further, the decision for one member to migrate is often made by the family unit, and has profound impacts on all family members. Despite the centrality of families in the migration process, most studies of the SAWP have paid scant attention to the role of and impacts on families. This is ironic given that the Mexican program is predicated on workers having families, supporting families and returning to families (McLaughlin 2010). By foregrounding specific experiences of individual families, we deepen understanding of the ways in which profound precarity and poverty drive SAWP migration. Centring on families' use of remittances, our ethnographic research is based on in-depth interviews not only with workers, but also with their spouses and children. In addition, to get a better understanding and overview, among other things, of impacts of remittances on children's educational success and opportunities, we interviewed SAWP children's teachers and principals. Our family-centred evidence clearly identifies patterns of remittance sending-amounts sent, timing, recipients of remittances, and remittance uses-suggesting that remittances primarily constitute, in the context of extreme poverty, significant but nevertheless precarious contributions to ongoing family survival. We conclude that remittances reduce poverty and precarity but at the same time reproduce precarity in different forms.

The research findings presented here are drawn primarily from interviews with SAWP workers from Mexico and their families. Mexico is by far the largest provider of SAWP workers, accounting for about two thirds of the total who come to Canada each year. Jamaica is the second largest participant country. In 2011-12, 21 semi-structured interviews were conducted with Mexican and 
Jamaican workers in Southern Ontario towns near to where large numbers of SAWP workers are employed. These interviews were used to gain insight into what workers see as key impacts of the SAWP on themselves and their families. Using information from these interviews, a longer semi-structured interview instrument was constructed for sixty additional interviews in 2012. These were conducted in the state of Guanajuato, northwest of Mexico City in central Mexico.7 Of Mexico's 32 states, each of which sends workers to the SAWP, Guanajuato receives the third largest amount of remittances and sends the fourth highest number of workers (1150 workers in 2012). Almost all workers come to Canada from rural areas of the state.

The criteria of selection for those interviewed were that they have been coming to Southern Ontario to work under the SAWP for a minimum of five years and that they have families with children. In total, 60 participants were interviewed in Mexico in 2012, including 24 male workers, 16 spouses, 10 adult children of SAWP migrants, and four teachers and school principals. Interviews were conducted in Spanish in workers' homes and, in the case of teachers, in their offices. They were based on open ended questions and usually lasted for 60-90 minutes. Separate questions were answered by workers, spouses, adult children, and school teachers. Interviews were transcribed in Spanish and then translated into English, after which data were analyzed by themes and coded into NVivo. In addition to these research findings, this analysis draws on some preliminary data from 60 Jamaican SAWP workers and their families interviewed in 2013.

\section{REMITTANCES IN CONTEXT}

Justino and Joe ${ }^{8}$, two of the workers profiled in our research, give a sense of the limited but important benefits of long-term participation in the SAWP. Justino, 47 years old, has worked under the SAWP in southern Ontario fields, planting, cultivating and shipping produce to market, for twenty-four seasons. He works four to eight months a year. His hours vary widely, between three and ninety a week, but he normally works about sixty. He and his wife, Gloria, have two sons, Mario, 16, and Marco Antonio, 21. Marco Antonio says that life is hard in their home area in rural Mexico:

There's land, but you can't work it, you can't support your family here. [...] Do you know where you can get money? Nowhere. Everything you can see here is because of the money of those who go to work in the USA or Canada. [...]. The land is not productive. The cattle die of starvation. There's nothing here.

In Canada Justino often earns about $\$ 18,000$ a season and sends home $\$ 10,000$. "I bought my land," he says, "built the house, and now I have my children studying." Grateful for his education, his older son, an engineering student, says the remittances "changed my life." Justino's younger son is in high school. 
Like Justino, Joe, a 62 year old farmworker from Jamaica, has also been working in the SAWP for over twenty years. He and his wife Louise have two daughters, ages 27 and 31, who live with them, and a son, 36. Joe usually works three to four months each year in Canada, from forty to sixty hours a week. Before coming to Canada, Joe's working life in Jamaica was extremely precarious and poor. After he lost his job at a sugar estate when it shut down, he got a contract job but it barely paid for food for his family and left his mortgage in arrears. He tried buying and selling in the food market, and janitorial work, but the pay was so little and unpredictable that sometimes he had too little money to send his children to school. Since coming to Canada under the SAWP he has sent home as much as $\$ 400$ or $\$ 500$ every two weeks to pay off the mortgage and send his children to school regularly. Thanks to these remittances his daughters are now teachers and his son has a construction job and drives a taxi.

Workers such as Justino and Joe provide human faces for the consensus among researchers, which suggests that SAWP remittances substantially reduce families' transient poverty, but do little to address structural poverty by developing local labour markets (Basok 2000b; Binford 2013; Hennebry, 2006; McLaughlin 2009a; Verduzco and Lozano 2003; Colby 1997; Kapur 2004). An important possible exception is investment in children's education, providing the potential to allow future generations a chance at improved employment opportunities. Unfortunately, the current economic climate in Mexico and Jamaica is such that even those with post-secondary educations face a limited, extremely competitive job market (Binford 2013; McLaughlin 2009a). Binford argues that Mexican workers "evade" poverty while they are SAWP participants but few gain "the technological knowledge or the financial resources [...] to permanently improve their lots." The SAWP temporarily ends their "precarious and shifting existence." Many were part of a reserve army of labour before enrolling in the SAWP: "alternately employed and unemployed, supported at times by the extended family, involved in subsistence production but frequently on borrowed or rented land, moving between the city and the countryside [...]" (Binford 2013: 145). Verduzco and Lozano similarly conclude that "[u]ncertainty about income and the lack of employment are the principal motives for the worker to enter the [SAWP]" (Verduzco and Lozano 2003: 50).

Families depend on the repeated migration to Canada of men, and in about one in twenty cases, women. Due to repeated spousal and paternal absence much of the year, that migration imposes other kinds of precarity, especially related to emotional and physical security, on the families left behind, while providing varying degrees of greater support for the material preconditions of family life. Because rural families pool income from various sources, it can be difficult to specify which items were purchased by remittances. However, interviewees are clear about the kinds of things they buy, most frequently mentioning expenses related to housing, children's education, food, health care, and clothing. 
SAWP recruitment policies vary but generally focus on workers with dependents. Selection criteria help ensure that workers return home to their families, promoting family reunification in sending countries. Most are males with spouses, children and often other dependents; females are often single mothers. Those who come to Canada have distanced child care responsibilities while they are working in Canada. Workers are much more likely to return home to their sending countries if their spouses and children are not allowed to accompany them to Canada. ${ }^{9}$

Our data support Binford's (2013) finding that average remittances by SAWP participants from Mexico are close to what Mexico's National Statistical and Geographical Institute considers the poverty line for a family of four. ${ }^{10}$ The workers and families we interviewed report that the remittances help to meet important basic family needs to reduce their poverty. Furthermore, repeated migration under the SAWP implies less economic precarity than most jobs in local labour markets in Mexico. In effect, SAWP remittances allow many workers and their families to move from extreme poverty and precarity to more moderate levels of poverty and precarity.

As McLaughlin and Hennebry (2013) argue, SAWP workers' employment and legal status is inherently precarious. Following Goldring et al. (2009), they note that migrant workers' legal status is precarious for various reasons, such as their dependence on employers to stay in Canada and their inability to secure a permanent form of legal immigration status for themselves or their families in Canada. This legal precarity intersects with their employment precarity. Indeed, employment precarity, and hence income precarity is integral to the political construction of the SAWP: workers can be fired and deported largely at the employer's will, with no appeal; if injured or ill or otherwise unable to work at required efficiency, they can lose their jobs. Employers can change their work hours and contract durations without notice, shaped in part by factors external to the employment relationship including crop damage by extreme weather, plant diseases, and insects. Workers' jobs are very insecure, and with no right to bargain collectively as part of a union, there is little opportunity to secure future employment.

For these and other reasons, incomes are precarious; that is, they are subject to fluctuation, are unpredictable and can be terminated without notice. Moreover, wages are normally at the provincial minimum wage, with few being paid above this level. There is no overtime pay and benefits are few, including a complete exclusion from Employment Insurance benefits despite contributing mandatory payroll deductions into this federal government program. The remittance level is substantially further reduced by shared costs of air transportation, costs of meals and deductions for federal and provincial taxes, Canada Pension Plan, program administration and visa fees, private health insurance, costs of sending remittances, and accommodation contributions. ${ }^{11}$ 
These pressures on their incomes, combined with a steady stream of expenses each year, mean that most workers have little opportunity to save additional money in case of future job loss or reduction in hours. These employment circumstances therefore lead to a vicious cycle of precarity: it is precisely because workers' incomes are so precarious yet considered absolutely essential to their families' well-being that workers do not normally feel comfortable demanding better conditions, refusing unsafe work, or making any social or familial demands on their employers.

Workers' precarity is not necessarily the direct result of individual employer actions-although these can certainly worsen the situation-but is rather primarily rooted in larger structural dimensions beyond the control of both workers and employers. In Canada, growers face increasing pressures from international competitors, whose products can undercut theirs in part because agricultural workers in most countries are paid less than the Ontario minimum, have even fewer labour rights, and also often benefit from longer growing seasons. Moreover, the increasing concentration of pricing power in giant supermarket chains such as Loblaw, Sobeys, Walmart, Metro and Safeway means that many SAWP employers, who are food suppliers in these chains, defend their profits by making their employees work more flexible hours, more intensively, with fewer occupational health and safety protections, less training, and in poorer housing. Lower wages are also a way to defend vendor profits, and lower wages imply lower remittance levels.

The SAWP was initiated and is still justified based on the view that agriculture is a unique industry necessitating exceptional employment circumstances, requiring a "captive," just-in-time labour force that is not only paid the minimum wage, but is also flexible, productive and dependable (Basok 2002; Hennebry and McLaughlin 2012). Because there is little decently paid work available to them in Mexico and Jamaica where wages are a fraction of those in Canada-also largely due to inequitable global economic relations far beyond their control-most SAWP workers and spouses have little access to additional income to compensate for lower remittances.

Most workers migrate from areas that are suffering what Harvey (2003) terms "accumulation by dispossession": rural populations are being removed from the land and made economically disposable by agribusiness and forced into an increasingly precarious world of neoliberal globalization (137-82). 'Free trade' and export-oriented industrialization-including the export of labour as exemplified by the SAWP - expose them to increased competition from labour regimes in other parts of the world with even lower labour standards.

This precarity is also based on the power of Northern states such as Canada to transfer the costs of maintaining workers and their families to sending states. Temporary migrant worker programs shift most of the 'social wage' (such as public health care, public education, pensions, etc.) for migrant workers to poor sending states. This macrostructural precarity strongly shapes the individual 
precarity of workers and their families. As important as SAWP remittances are as lifelines for workers and their families, they do not allow escape from precarious poverty but rather reconstruct it along North-South lines.

\section{RECRUITING GUESTWORKERS FOR A SEGMENTED LABOUR PROGRAM}

Temporary foreign workers have a long history in Canada, notably in railways, mining, domestic work and other sectors. In the 19th and early 20th centuries Canada supported permanent migration by those of 'preferred' origins and built a "concealed guestworker system" around the state prerogative to deport non-citizen workers (Abella 1998). Today, as in the past, Canada's hierarchically segmented labour market ${ }^{12}$ is constructed around gender, 'race' and 'skill' as bases of exclusion, as exemplified in the late 19th century by male Chinese 'coolie' labour on British Columbia railways (Satzewich 1991; Hughes and Lenard 2012; Sharma 2006). Except for formal deportation, much of this temporariness in Canada was outside state regulation. Since the 1960s, however, the Canadian state has taken a more comprehensive directive role in regulating this labour market segmentation. In the 1970s Canada set up a control system for temporary workers under the Non Immigrant Employment Authorization Program, which prohibited workers from applying for permanent residency, required formal approval to change employers, and placed other restrictions on workers which became key features of lower-skilled streams in Canada's Temporary Foreign Worker Program.

The SAWP's recruitment focus is on landless and land-poor rural workers with little education, mostly farming day labourers and peasants from areas where pay is very low and uncertain (McLaughlin 2010: 88; Verduzco and Lozano 2003: 45). ${ }^{13}$ In Jamaica the rural focus of recruitment is less direct, but there is a "preference for rural candidates with agricultural experience" (McLaughlin 2010: 88). When SAWP workers earn income in Jamaica, most do so from farming, earning little and inconsistently. ${ }^{14}$ Only 18 percent report any income in Jamaica. Their farms are small and prices for their agricultural products are volatile (Russell 2003). Similar to the overlapping multiple intersecting forms of oppression of migrant agricultural workers in the United States (Holmes 2013), in Canada, these workers' 'race' and ethnicity, their lack of Canadian citizenship status and lower class positions converge to justify their placement at the bottom rung of a hierarchy of agricultural working relations. In an industry that is profoundly disciplined by international competition, they have the least power or say over their jobs, tend to be assigned the least desirable (and sometimes most unsafe) tasks, earn the worst income, and have the least employment security in the process.

As noted, recruitment also focuses on workers with dependents. In addition to targeting rural workers with limited education, Mexico's Ministry of Labour 
targets those who are the main economic support for their families (Binford 2013: 49). Basic criteria include a preference for married men with children and/or dependents, or women who are single mothers and/or with dependents (Munoz Carillo n.d., 10; Pantaleon 2011: 92). ${ }^{15}$ Most Mexican SAWP workers are 25-44 years old, ages when they are most likely to have families (McLaughlin 2010: 85). Most female participants are single mothers (Hennebry 2012: 5), ${ }^{16}$ and most males are in marital relationships (Binford 2006: 3; McLaughlin 2010: 85). ${ }^{17}$ Although recruitment to the SAWP in Jamaica is not based explicitly on workers being married, in practice most are married or in common law relationships (McLaughlin 2009a), and most spouses are dependents (Russell 2003: ii). While most support spouses and children, others also support elderly parents or family members with illnesses or disabilities. In many cases, communal kinship obligations may generate expectations that an entire extended family should rely on the remittances of a migrant.

Administratively the SAWP operates as a public-private industrial relations system. Under the federal government's restructuring of TFWP administration, Employment and Social Development Canada is now the lead department, processing employer applications and temporary work permits. Performing functions that in other countries are conducted by government agencies (Preibisch and Hennebry 2012: 67), the Ontario agricultural employers' Foreign Agricultural Resource Management Services (FARMS) coordinates the processing of requests for workers (FARMS 2013). Sending country governments have responsibility for worker recruitment, discipline, and health screening. Employer requests, supported by federal government Labour Market Opinions (recently renamed Labour Market Impact Assessments) stating that Canadian citizens and permanent residents are not available for the work, drive much of this process.

SAWP workers' ability to access rights is limited by their employment and immigration precariousness as well as their employment within agriculture, an industry with various labour rights exemptions, including exclusion from collective bargaining rights in Ontario (McLaughlin and Hennebry 2013). They are contracted to individual employers and have little or no choice regarding the work they do or the duration of their contracts. Unlike live-in caregivers and some other temporary foreign workers, they have no pathway or mechanism to gain permanent residency status. Even where rights are formally available (e.g., occupational health and safety provisions), workers' extreme dependency on employers often precludes their exercise. Contrary to Canadian human rights legislation, employers may choose workers based on gender and country of origin (McLaughlin 2010: 85). As noted, employers may deport workers if they are injured, deemed undesirable, or no longer needed. The Mexican and Jamaican Ministries of Labour can punish those who receive negative reports from employers, or are not requested back, by suspending them from the program (Basok 2002; Binford 2009: 508; McLaughlin 2009a). In light of such dependencies 
and vulnerabilities as 'guest workers'18, SAWP migrants have much in common with indentured servants. ${ }^{19}$

\section{NEOLIBERAL 'PUSH’ AND ‘PULL’}

The SAWP is part of a new global division of labour. Alongside offshoring production to cheap, authoritarian labour regimes in the global South, employers principally in the global North and parts of the Middle East are importing cheap, flexible labour from the South. Historically shaped by colonialism, precarious labour has long been prevalent in the South. To this precarity has been added a weakening of trade protections for domestic industries, public sector privatization, and reductions in spending on public services. Growing streams of pauperized workers, including displaced peasants, have created even more gargantuan pools of surplus labour. In the context of neoliberal globalization since the 1970s in particular, and by requirements for low-skilled labour that is socially constructed by low wages, bad working conditions, and low social status in particular economic sectors, large numbers of Southern 'guest workers' are working in the bottom segments of Northern labour markets. In addition to Canada and the US, many countries in Europe and oil rich countries in the Middle East are among the states that have promoted temporary labour migration programs. In contrast to earlier periods, the current period is strongly shaped not only by labour receiving states but also by "labour arbitrage" by sending states that promote the export of guest workers to reduce domestic unemployment and gain remittances (Rodriguez 2010: $x$ ). Together, both sending and receiving states construct 'pull' and 'push' factors shaping this labour migration.

The International Monetary Fund's structural adjustment programs and the North American Free Trade Agreement have been key factors accelerating the destruction of much of Mexico's and Jamaica's agriculture. Subsidized agricultural imports from the North and direct entry of large scale industrial agriculture have weakened and eliminated small farmers. Mexican governments have cut subsidies that sustained small farmers, privatized the rural banking system, closed state purchasing and distribution programs, and amended constitutional protection of communal lands that supported a third of Mexico's population to foster privatized land consolidation. In the context of US policies, including agricultural dumping, prices of key Mexican agricultural exports to the US fell sharply in 1997-2005, resulting in a loss of over 10 percent of the value of Mexican agricultural exports to the US (Wise 2010: 35).

These reforms were part of a broader neoliberal transformation of Mexico's economy which included forced migration. From 2000 to 2005 alone Mexico lost one and a half million jobs, mostly in the rural economy. As the crisis in agriculture in Mexico (and Jamaica) deepened, more small landowners became semi-proletarian, working for wages on larger farms or in cities. According to the World Bank, extreme rural poverty in Mexico increased rapidly from 35 percent 
in 1992-1994 to 55 percent in 1996-1998, after the implementation of the NAFTA. By 2010 half of Mexico's population was living in poverty, and one in five, mostly in rural areas, were in extreme poverty (Bacon 2013: 11).

As in Mexico, most of Jamaica's rural population is dependent on agriculture. Less than 1 percent of farmers own 57 percent of Jamaica's farm acreage, leaving most of the remaining 99 percent of farmers subsisting on small plots (Russell 2003). Like their Mexican counterparts, Jamaican farmers have been undercut by cheap agricultural imports from subsidized Northern industrial operations. External economic pressures generate circumstances that push people to migrate, attracted by another form of neoliberal precarity under the SAWP.

SAWP employers benefit from this displacement and impoverishment of rural workers not only because they have a huge supply of cheap, flexible labour, but also because Canadian employers pay no taxes to support the education, transportation, medical and other social support systems in the sending countries which thus bear the social costs of this migration. SAWP workers help to fill increasing gaps in public spending through their remittances.

\section{REMITTANCE USES}

Prior to joining the SAWP, most interviewees were unemployed, underemployed, or had very low-paying jobs and were the primary income earners in their families. Consistent with the findings noted above in other studies, the need for income to ensure the well-being of their families was the driving force for going to Canada. As Binford (2003) has stressed, government selection of participants who are poor, fundamentally constrains these workers' ability to use remittances to promote economic development, for example by buying agricultural land or investing in businesses in the sending countries. The need to provide for their basic needs such as food and housing takes precedence over investment in productive activities.

Most interviewees reported that they send home remittances weekly or bi-weekly, with some sending them monthly. Variation in amounts of these remittances reflects changing income levels which are linked to number of work hours (often linked to weather conditions, growth cycles of crops and crop yields), and contract duration (longer contracts often imply higher remittance sending capacity ${ }^{20}$ ).

The following sections summarize the use and importance of remittances, as described by interviews with workers, their family members and community members. These participants were asked open-ended questions about what they used remittances for and the difference that these remittances made in their lives. Interview themes are presented in order of frequency of their mention. This cannot be considered an exhaustive list. However, it does give us a sense of the items that workers and their families deemed most significant in terms of remittance purchases. 
Summary of Findings

Among Mexican Respondents

\begin{tabular}{|l|c|c|}
\hline \multicolumn{1}{|c|}{ Theme } & $\begin{array}{c}\text { Number of } \\
\text { Respondents } \\
(\mathrm{N}=60)\end{array}$ & $\begin{array}{c}\text { Number of } \\
\text { References }\end{array}$ \\
\hline Housing & $46(77 \%)$ & 87 \\
\hline Education & $35(58 \%)$ & 75 \\
\hline Food & $32(53 \%)$ & 66 \\
\hline Health Care & $27(45 \%)$ & 46 \\
\hline Clothing & $23(38 \%)$ & 32 \\
\hline Debt payments & $19(32 \%)$ & 28 \\
\hline Savings & $20(33 \%)$ & 24 \\
\hline Land and Livestock & $18(30 \%)$ & 24 \\
\hline Misc./Other* & $41(68 \%)$ & 80 \\
\hline
\end{tabular}

*This residual category consists of a disparate range of purchases such as computers, blenders, telephones, fumigation, tractors, trucks, furniture, house repairs, fertilizer, washing machines, etc.

\section{HOUSING}

Housing was the most common theme respondents discussed. Workers often build their houses gradually, with each SAWP season allowing for the addition of a new room or housing component. Thanks to remittances, says Mexican worker Alfredo, he has been able to build a more secure house: "Now I'm not afraid of storms [whereas before I] thought my house would go away [...] Now we can rest peacefully." Remittances are also frequently used to purchase household appliances. Alfredo, for example, bought a stove and a fridge and built a bathroom, explaining: "We didn't have a proper bathroom. We had to run to the bushes. Now we don't".

\section{CHILDREN'S EDUCATION}

Education was the second most frequently mentioned use of remittances. SAWP remittances pay for tuition, uniforms, transportation, school supplies, special school events, and graduation celebrations. Parents dream that schooling will help their children escape their own fate. Typical of many, a worker explains: “That's the reason I'm working [in Canada]. To provide [my children] with an education, so they won't work doing what I do. I wouldn't like them to suffer as I do." Theirs is a determined hope that their children can escape poverty and precarity if they have enough schooling. Then, says an adult son of a SAWP worker, the children "will no longer need Canada or their father. They themselves, with their studies, will come out ahead." Otherwise, the wife of another SAWP worker fears, without education the children will "become like vagrants." 
For most, it is only the remittances that make this dream seem feasible. Otherwise, low wages at home make it almost impossible for most children to go beyond primary school. One worker's wife asks:" Do you know how much they earn weekly [in Mexico]?" And answers: "Five hundred, six hundred pesos [CAD $\$ 40-\$ 48]$. Do you think that would be enough to provide education for our children? No." A SAWP worker explains that his remittances mean that his children do not have "to choose between school and food." The "community has no income," a teacher emphasizes, but thanks to remittances "the number of kids attending school has increased." His observation is supported by Verduzco and Lozano's analysis of linkages between parents' participation in SAWP and the average schooling of their children. Controlling for differences in the ages of the workers, they found that the average number of years of schooling of the children was higher for those who worked more years in the SAWP (2003: 109-110).

For some, SAWP remittances are enough to give their children a better education; for others, especially those with more children, they are not. Some are forced to choose to educate only some of their children. Consistent with rural Mexican patriarchal norms, some give their sons priority over their daughters. Thus, one worker educated his son, an industrial engineer, but not his daughter, who had to quit school to work at "hair cut stuff." In other cases, parents choose to educate only their younger children. For example, a mother of six reported that the remittances were not enough to educate all her children, so her three older children were not allowed to go to secondary school.

With so many being displaced from the land, and massive unemployment/underemployment in Mexico, a secondary or tertiary education is increasingly required to obtain employment. However, over the past thirty years or so the proportion of standard jobs in Mexico has declined, and even standard jobs are often poorly paid with few benefits. University graduates are increasingly competing for jobs that previously required only secondary education. Consequently, SAWP workers' children face growing barriers to escaping their parents' poverty. Public schools in rural Mexico are overcrowded and the education they provide is often inadequate. This makes it very hard for children to pass exams to enter university. Few of those who do manage to enter university finish their degrees. Those who do are often "disappointed with the wages and working conditions that follow graduation" (Binford 2006: 9-10).

\section{FOOD}

Buying food was the third most frequently mentioned expenditure. Several workers said that before going to Canada they did not always have enough to eat. Many ate primarily what they could grow themselves, which meant a fairly restricted diet. Remittances allow them not only to eat more regularly, but also more expensive and diverse food. While in many cases this may increase nutritive intake, in other cases expanded diets include high fat, processed, high sugar 'junk 
food.' Whereas prior to migrating a Mexican family might subsist primarily on beans and tortillas, after migrating they might add meat, dairy products, fruit and celebratory items like birthday cakes, to their menus. Explains a migrant worker's wife:

We didn't have enough to eat. [...] We had nothing but beans to eat, one pepper in the mortar and pestle. To drink we had atole [corn-based gruel] [...] Now [her husband] says: 'Now I'll go, I'll bring fish broth, beef broth.' Well the food is different (better), since he has the opportunity to go away [to Canada].

"Everything we have here is thanks to that job," another wife adds. We spend on average \$20 Canadian daily for food." An adult child remembers that after his father sent remittances from Canada, his family "ate what we wanted. There were many things we were craving, like apples, oranges, bananas, everything. We had everything after he started going to Canada. [...] That was a big change."

\section{HEALTH CARE}

Health care was the fourth most frequent remittance expenditure reported. Although they have health care coverage while in Canada, many migrants wait to pay for doctors' visits, surgeries or other procedures when they return to Mexico because they fear the effects of missing work and/or appearing ill on the job. Recent research has demonstrated that illnesses and injuries among workers in agriculture, one of Canada's most dangerous industries, are common and may result in long-term impacts and costs for which workers are not adequately compensated (McLaughlin 2009a, 2009b; McLaughlin et al. 2014a, 2014b). A recent analysis found that nearly 1,000 workers had been repatriated for explicit medical reasons over the past decade, indicating that health issues, when discovered by the employer, can result in job termination (Orkin et al. 2014). These numbers do not include the scores of workers who endured medical conditions while hiding them from employers, a common phenomenon given the well-founded fear of early repatriation (McLaughlin 2009a).

Although our research did not focus on health concerns, workers regularly discussed health expenses as a major source of remittance spending. Health issues requiring medical interventions ranged from migraines, fevers and depression to thyroid problems, eye conditions, musculoskeletal concerns, diabetes and cancer. Respondents estimated that a simple check-up for an acute health concern cost 350-500 pesos (CAD \$28-40) in doctors' fees, plus whatever medication is recommended. Such an appointment would take a week's worth of Mexican work to pay for. A migrant explained that in Mexico "they pay very cheaply. The little you make, what they make in one week, in one day [is paid] to the doctor."

In addition to their own health care expenses, various participants discussed their family members facing complex or serious health problems that were very 
costly. "Almost all the money I made was spent so that they could cure (my daughter)," one migrant recalled. Another:

My wife has given birth. Surgeries, cesarean, that is very expensive. If I wouldn't go there (to Canada), I couldn't afford the hospital. My youngest son had to stay in the hospital in an incubator. We've spent a lot of money because of that. He was very fragile. Then he had a liver condition, he could only drink no lactose milk. That is expensive too. So there goes the money.

With increased money to spend on medical expenses, workers and their families feel that their health has benefitted: "Now it's easier," a worker says. "You're less stressed because of lack of money for school, for a doctor. You know the doctor won't fix you with a smile." In addition to paying for the health care costs of their wives and children, there is a social expectation that the migrant will support his extended family, including unemployed siblings and elderly parents, in medical crises. Another explains that his remittances have been used for:

My mom's medication [...] about 2,500 (pesos; about CAD \$200) [...] plus the doctor's visits. Well they're a thousand pesos per appointment and for the transportation [...] one pays $220 \ldots$ almost all of the money has gone that way. (Due to remittances) we haven't felt tight on money right now with my mom's routine check-ups. Well with my father too, since he suffers from lung problems. And my mom right now has a clogged vein in her left leg that would frequently, before, give her pain and she couldn't walk. She was at risk that they'd have to amputate it but thank God we had someone who told us about a doctor who is a specialist and well thank God now she walks.

Given such expensive health problems, and the lack of comprehensive care provided in either Mexico or Jamaica, many say they want governments to provide them and their families with health insurance not only in Canada, but also in their home countries:

You spend money because the social security doesn't cover that [...] What you earn [in Canada], you spend it here in sickness. [...] We would like from the [Mexican] government insurance for our families [...] So, in case someone gets sick, you come back, you get sick, can you imagine a serious disease? We're talking about more than 5000 dollars, 7, 100, 10 thousand, and if it's the only money you could bring from [Canada], then you will spend it all. Then you have nothing, so, if you have someone sick, it means you went to Canada for free.

\section{CLOTHING}

Clothing was the fifth most frequently cited expenditure. In particular, school uniforms for children were mentioned numerous times as an expensive item purchased with remittances. They also bought special clothing for graduations, 
parties and other celebrations. For many, clothing is not only a physical necessity (to keep warm, dry, etc.), but also a social necessity. Clothing is a status symbol in rural communities where proper attire, such as mandatory school uniforms, dress clothes for attending church, and formal attire for graduations, birthday parties, weddings, etc., is needed for social acceptance and participation with dignity. "If there's a party and my daughters need a dress, I buy it," a Mexican mother explained, "but I tell them not to take advantage of it because we don't know how hard does their father have to work in order to provide money for us." Likewise, a migrant, when justifying his absence to his children, reminded them that if he didn't go, his daughters would have to endure "see(ing) your little friends with new dresses and you [without them]."

\section{DEBT}

The sixth most common response was the use of remittances to make debt payments. When living in poverty it does not take much to slip into debt. Respondents discussed going into debt over school fees, medical expenses, or the purchase of a small animal, while others went into debt for larger purchases such as a car, some land, or home construction. The most common reason given for debt was medical expenses. Columbia, a Mexican migrant wife explains:

Well, we got sick. Then he bought some land and fenced it. The job he had was not well paid [...]. We had to borrow money. [...] He owed almost $\$ 40,000$ pesos [about CAD \$3200], and he finally paid that back. When he sent money he instructed me who to go to pay back money we owed [...] I'm so glad we got rid of that big debt. We couldn't afford to pay them back for the last three years, and I was really ashamed. He is less stressed now. Since we paid that money back, our lives changed. We are a happy family.

During their first years in Canada, many migrant families, like Columbia's, simply pay off debt already accumulated. Paulina, another wife, explains how her family accumulated significant medical bills: "when he got back from Canada it was just paying and paying. (..) The first years that he went, it was almost all just paying (the debt)..."

The money from Canada eliminated the need for some families to accumulate further debts, but in other situations the money did not go far enough. "Here everything is very expensive," a worker said. "So the money is just not enough [...]. You have to borrow money from someone else, or from the bank." When the worker returns home and remittances stop flowing, expenses quickly add up, and the family never knows exactly when (or if) the worker will return to Canada, making it difficult to plan financially. Josefina, a worker's wife, explains: "He only goes for a small amount of time [to Canada] and we have a lot of expenses [while he's not working]. It's just taking and taking out little by little until there's 
nothing left." Some borrowed from banks, but most used informal lending systems with neighbours, extended family or fellow migrants, based on relationships of trust. For example, Josefina's family borrows money at a low interest rate $^{21}$ from other families who have been participating longer in the SAWP and have more savings. "There are people that lend it and there are people that do you the favour, just like that, that say: "Today it's you and maybe tomorrow it's me." Another migrant wife reports how a neighbour helped her:

When she knew I was sick she helped me. We were going to sell the house to pay the medical bills, and she told me not to, that she would help me with the bus tickets and with whatever I might need. That's why I could keep my little store too. She told me to take care of it and to face my condition, to keep working, not to be depressed, not to feel lonely, that I was being helped. That's how, thank God, I defeated cancer.

\section{LAND, LIVESTOCK, PRODUCTIVE INVESTMENT AND SAVINGS}

There were fewer references to land, livestock and productive investment in our interviews. Some workers buy small plots of land to grow vegetables, to raise a few pigs or cattle to help feed the family, and to provide land on which their children can build homes. Even those who are able to buy land to grow crops face additional precarity because of the poor quality of much of the land, and a general lack of water in the area. Explaining this ongoing precarity, a worker explained that his is "not very good land, has no water. Sometimes you can't grow anything. This year, for instance, there was nothing. Everything got lost."

Similar to what other research has found (e.g. Binford 2013; Hennebry 2006), our interviewees only occasionally mentioned that they used remittances to open a small business, such as a local taxi or trucking venture. Some workers reported buying cars or trucks. Workers also live on saved remittances when they are too sick or old to work, and to provide a small inheritance for their children. In these ways, it is possible to reduce precarity and poverty but not, in most cases, to overcome it.

\section{PRECARIOUS REMITTANCES}

Most Mexican workers and spouses 22 report that after they ration out the remittances they are sometimes able to save what one wife calls "a little bit at a time." The longer the worker participates in the SAWP, the more likely it is that remittances can contribute to family savings. Even as little as a month can make a difference, says one worker. His last SAWP contract was for five and a half months. The remittances he sent home were enough "to survive" but if he could work a month longer it "wouldn't be bad" [would improve his family's living standard]. Another says the remittances are not enough if he only works four 
months "but it helps. The children have better clothes. They eat a little bit better." The wife of another worker says that if her husband is "able to work whole weeks in Canada then the remittances are enough but usually he can only work two or three days a week, so it's not enough except to pay for groceries."

Often the remittances are not enough and they run out of money. "Right now," says a SAWP worker's wife, they have run out of money and "we don't know where we're going to [...] get some [money], [maybe] from someone who has some to lend us." When her husband returns to Canada and sends her remittances "we'll be paying [back the loan] little by little." One worker says that sometimes the money he sends home is not enough. When his family does not have enough to eat, they "go to the hill" to find nopales [cactus leaves] to eat. "You know how to suffer, your family is used to suffering. You suffer."

The wife of a different worker says that sometimes the remittances are enough and sometimes they are not. When they are not enough, she rations the family food carefully. For another worker the remittances are enough to eat well "more or less" but not enough to allow him to send his daughter to high school. She wanted to go "but I couldn't [send her] because I didn't have enough money." The wife of another migrant reports that the remittances "help a lot" but are not enough. "We have six children so it is not enough." She "had to take the older [child] out of school because I couldn't afford it." In yet another case, the adult son of a migrant worker stated that so far the remittances have been enough to pay his school expense but that the remittances his father can send vary a lot each year. For other expenses he depends on help from his uncles.

If a worker is able to find work when he is home between SAWP seasons, that can make a difference. Yet often there are no jobs. "When we come back [from Canada], says one worker, "we're jobless. There's no work here. [...] When I go back to Canada, I'm broke. Why? Because [remittances] are not enough." Another says the remittances are not enough "because if you don't work here [Mexico] too then you don't have enough money. [...] If you can't, then you go back to Canada with no money." Even if they can find jobs, they are often too precarious and badly paid. The pay he's able to make in Mexico is so bad, says one SAWP worker that it's "not even enough for food." "Perhaps we can find a job that lasts [only] one, two or three days per week," another worker says. "That's why there's no money, no nothing."

According to Binford, on average SAWP workers send home annual remittances that are equivalent to 2.2 minimum Mexican salaries. Mexico's National Statistical and Geographical Institute considers two minimum salaries the poverty line for a family of four. However, since this poverty line is calculated on the cost of a basic food basket and does not include the costs of education, health care, clothing, utilities and other basic needs, many researchers conclude it is too low. Moreover, the average family size in Binford's study was five. About half the workers in Binford's study had incomes below this 2.2 minimum wage poverty line (2006: 3-4). 
Justino and Joe and other SAWP workers are caught in fundamental contradictions of neoliberal underdevelopment. There are too few jobs at home, they are too precarious and they pay too little to allow their families and communities to survive. By enabling workers to send remittances home to their families and other dependents, the SAWP provides them a desperately needed and beneficial path to less precarity and to less poverty. For many workers and their families and other dependents living on the edge of survival the remittances are-literally - a lifeline. Important as these remittances are, they often do not provide enough to meet the needs of these workers and their dependents. Nor do the remittances provide an ability for most, by investing in land and small businesses, or in their children's extended education, to help the next generation escape their parents' precarious poverty.

Every worker, spouse, child and teacher we interviewed was emphatic that they need the remittances they receive from the SAWP. About this there can be no doubt. There is also no doubt that the SAWP remittances provide no genuine alternative to precarious poverty. Rather, for most, the SAWP provides a more regulated form of precarity at lower levels of material deprivation. That the SAWP and its remittances are this better option is a poignant testament to economic forces driving so many in Mexico and Jamaica and in other areas in the South to leave their families in order to work in these lowest segments of Northern labour markets.

\section{NOTES}

1 In addition to the SAWP, these include an agricultural stream for workers from any country, a low-skill occupation stream for all agricultural commodities, including those that are outside the list for SAWP workers, and a stream for higher skill occupations in agriculture. The federal government recently announced it would divide Temporary Foreign Worker Programs into two sets of programs: Temporary Foreign Worker Programs for foreign workers entering Canada at employer request following approval through a new Labour Market Impact Assessment (LMIA, and International Mobility Programs for foreign workers not subject to LMIA (Canada 2014: 1).

2 According to the Mexican government, in 2012 on average SAWP workers were in Canada 5.7 months (6 months in Ontario) (STyPS n.d.: a).

3 Remittances include the amount of money SAWP workers sent home during the year, plus the amount they brought with them to Mexico. These data are based on reports SAWP workers complete for government officials on returning to Mexico annually.

4 World Bank 2013: 1,2.

5 Bank of Jamaica 2013: 7, 10.

6 Verduzco and Lozano note a trend in which during their initial migrations to Canada, SAWP workers generally allocate more remittances to family consumption or to pay off debts. As they continue coming to Canada their remittances are devoted more to longer-term needs such as enlarging their homes (2003: 114).

7 The interviews were conducted by Aaraón Díaz Mendiburo. 
$8 \quad$ All names used are pseudonyms.

9 Unlike policy in the US, South Africa and Canada, all European states have allowed family reunification of guest workers (Hahamovitch 2003: 87).

10 This poverty line is based on a basic food basket and excludes other basic costs, such as education, health care, clothing, utilities, etc. (Binford 2013: 119).

11 Workers from the Caribbean contribute 5 percent of their pay to program administration costs, Mexican workers contribute to private health insurance premia, and all workers now contribute to the costs of their accommodation via a utility fee of $\$ 2.16$ per working day. See:

http:/ / www.farmsontario.ca/ program.php?divname=2013RatesPeriods.

12 On the concept of labour market segmentation, see Gordon, et al. (1982).

13 About 40 percent of Verduzco and Lozano's survey of SAWP workers reported having no work for at least two weeks in a year; their average duration of unemployment was 11 weeks (2003:50).

14 On average they found work for only one and a half months and their average earnings from farming in 2001 were CAD \$1, 646 (Russell 2003: Tables 4.6, 4.7).

15 McLaughlin cites 2006 Mexico Ministry of Labour data indicating that 96 percent of SAWP workers had children (81 percent had two or more children) and others may have had additional dependents (e.g., elderly or sick parents) (2010: 85). In Russell's sample, the average number of dependents per Jamaican SAWP worker was 3.9 (n.d: $3)$, over 55 percent of whom were children less than 18 years of age. The others were spouses, adult children and seniors (n.d.: 30, Table 4.10). Pantaleon cites statistics which indicate an average of 2.7 children for SAWP workers from Mexico (2011: 92). This is similar to Binford's Mexican sample where the average household included five persons, usually three children in addition to the worker and his spouse (2006: 3).

16 To ensure that women are not pregnant, for example, women from Caribbean countries are required to take pregnancy tests before they board planes to Canada (Hennebry and Preibisch 2012: 25).

17 Married includes common law relationships.

18 In postwar Germany the term Gastarbeiter (guestworker in English) replaced the term Fremdarbeiter or "alien workers" signifying "sub humans" which had been used to identify Nazi slave labour (Hahamovitch 2003, 70).

19 In the $19^{\text {th }}$ century and early $20^{\text {th }}$ century European countries, indentured servitude replaced colonial slavery, binding indentured servants to work contracts with specific employers for a specified number of years [Hahamovitch 2003: 72].

20 This partly reflects fixed costs such as airfare, work clothing, etc.

21 She borrows 1000 pesos and pays .25 percent interest per month.

22 Quotations in this section are from interviews with Mexican workers and their families only.

\section{ACKNOWLEDGEMENTS}

This article was made possible by the support of funds from the United Way Toronto-McMaster University SSHRC CURA project on Poverty and Employment Precarity in Southern Ontario. The authors thank Josephine Eric for research early in this project, Kelly O'Sullivan for research assistance, and 
interviewers from Development Options in Jamaica. We are grateful to the workers and their families whose voices are the heart of this article.

\section{REFERENCES}

Abella, Irving. 1988. "Foreword". Pp. vi-xi in Whence they Came: Deportation from Canada 1900-1935, edited by Barbara Roberts. Ottawa: University of Ottawa Press.

Bacon, David. 2013. The Right to Stay Home: How US Policy Drives Mexican Migration. Boston: Beacon Press.

Bank of Jamaica. 2013. Balance of Payments Remittance Report. Kingston: Bank of Jamaica.

Basok, Tanya. 2003. "Mexican Seasonal Migration to Canada and Development: A Community-Based Comparison." International Migration 41(2): 3-26.

-------. 2002. Tortillas and Tomatoes: Transmigrant Mexican Harvesters in Canada. Montreal: McGill Queens University Press.

-----. 2000a. "He Came, He Saw, He ... Stayed: Guest Worker Programmes and the Issue of Non- Return". International Migration 38(2): 215-38.

-------. 2000b. "Migration of Mexican Seasonal Farm Workers to Canada and Development: Obstacles to Productive Investment". International Migration Review 34(41): 79-97.

Binford, Leigh (2013) Tomorrow We're All Going to the Harvest Austin: University of Texas Press.

-------. 2009. "From fields of power to fields of wheat: the dual process of constructing temporary migrant labour in Canada". Third World Quarterly 30(3): 503-17.

------. 2006. The Seasonal Agricultural Workers Program and Mexican Development Ottawa: Canadian Foundation for the Americas (FOCAL) Policy Paper 06-07.

Castles, Stephen and Mark Miller. 2009. The Age of Migration. New York: Guilford Press.

Colby, Catherine. 1997. From Oaxaca to Ontario: Mexican Contract Labor in Canada and the Impact at Home. Davis, CA: California Institute of Rural Studies.

Crowley, H. and M. Hickman. 2008. "Migration, Postindustrialism and the Globalized Nation State". Ethnic and Racial Studies 31(7): 1222-1244.

Dussell, Enrique. 1998. "Recent Structural Changes in Mexico's Economy: A Preliminary Analysis of Some Sources of Mexican Migration to the United States". Pp. 55-74 in Crossings: Mexican Immigration in Interdisciplinary Perspectives, edited by Marcelo Suarez-Orozco. Cambridge MA: David Rockefeller Center for Latin American Studies.

FARMS (Foreign Agricultural Resource Management Services) website. Accessed September 232013 www.farmsontario.ca.

Gordon, David et al. 1982. Segmented Work, Divided Workers. Cambridge: 
Cambridge University Press.

Canada. 2014. Overhauling the Temporary Foreign Worker Program: Putting Canadians First. Ottawa; Government of Canada (WP-191-06-14E)

Hahamovitch, Cindy. 2003. "Creating Perfect Immigrants: Guestworkers of the World in Historical Perspective". Labor History 44(1): 69-94.

Harvey, David. 2003. The New Imperialism. New York: Oxford University Press.

Hennebry, Jenna. 2012. Permanently Temporary? Agricultural Workers and their Integration into Canada. Institute for Research on Public Policy Study No. 26.

Hennebry, Jenna and Janet McLaughlin. 2012. The Exception that Proves Rule: Structural Vulnerability, Health, Risks, and Consequences for Temporary Migrant Farm Workers in Canada. Pp. 117-138 in Legislating Inequality: Canada's Temporary Migrant Worker Program edited by P. Lenard and C. Straehle. Montreal: McGill- Queen's University Press.

Hennebry, Jenna, Janet McLaughlin and Kerry Preibisch. Forthcoming. 'Out of the Loop': (In)access to Health Care for Migrant Workers in Canada . Journal of International Migration and Immigration.

Hennebry, Jenna and Kerry Preibisch. 2012. “A Model for Managed Migration? Re-Examining Best Practices in Canada's Seasonal Agricultural Worker Program". International Migration 50: 19-40.

Holmes, Seth. 2013. Fresh Fruit, Broken Bodies: Migrant Farmworkers in the United States. Oakland: University of California Press.

Hughes, Christine and Patti Lenard. 2012. Legislating Inequality: Canada's Temporary Migrant Worker Program. Montreal: McGill-Queen's University Press.

HRSDC (Human Resources and Skills Development Canada). 2013a. “Agreement for the Employment in Canada of Commonwealth Caribbean Seasonal Agricultural Workers - 2013". Retrieved September 212013

www.hrsdc.gc.ca/eng/jobs/foreign_workers/agriculture/sessional/sawpcc2013.sht $\underline{\mathrm{ml}}$

----. 2013b. "Agreement for the Employment in Canada of Seasonal Agricultural Workers from Mexico - 2013". Retrieved September 212013 www.hrsdc.gc.ca/eng/jobs/foreign_workers/agriculture/sessional/sawpmc2013.sh $\underline{\mathrm{tml}}$

Jamaica Ministry of Labour and Social Security. 2013. Annual Report 2012/13 Kingston.

Kapur, Devesh. 2004. "Remittances: The New Development Mantra?" G-24 Discussion Paper 29. UNCTAD, New York: United Nations.

Lopez-Cordova, J. Ernestor and Alexandra Olmedo. 2007. "International, Migration, remittances, and Development: An Overview". Integration \& Trade 27(11): 1-19.

Massey, Douglas and Emilio Parrado. 1998. "International Migration and Business Formation in Mexico". Social Science Quarterly 79(1): 1-20. 
McLaughlin, Janet. 2010. “Classifying the 'ideal migrant worker': Mexican and Jamaican transnational farmworkers in Canada". Focaal: Journal of Global and Historical Anthropology 57: 79-94.

------. 2009a. Trouble in Our Fields: Health and Human Rights Among Mexican and Caribbean Migrant Farm Workers in Canada. Doctoral Thesis, Anthropology, University of Toronto.

-------. 2009b. "Migration and Health: Implications for Development." Policy Paper (2). The Canadian Foundation for the Americas Labour (FOCAL) Mobility and Development Project.

Retrieved September 232013

http://www.focal.ca/pdf/Migrant percent20Health percent20McLaughlin percent202009.pdf

McLaughlin, Janet and Jenna Hennebry. 2013. “Pathways to Precarity: Structural Vulnerabilities and Lived Consequences for Migrant Farmworkers in Canada". Pp. 175-194 in Producing and Negotiating non-Citizenship: Precarious Legal Status in Canada, edited by Luin Goldring and Patricia Landolt. Toronto: University of Toronto Press.

McLaughlin, Janet, Jenna Hennebry and Ted Haines. 2014a. "Paper versus Practice: Occupational Health and Safety Protections and Realities for Temporary Foreign Agricultural Workers in Ontario." Pistes: Interdisciplinary Journal of Work and Health April.

McLaughlin, Janet, Jenna Hennebry , Donald Cole and Gabriel Williams. 2014b. "The Migrant Farmworker Health Journey: Stages and Strategies." IMRC Policy Points. International Migration Research Centre, Waterloo, Ontario. www.wlu.ca/imrc.

Munoz Carillo, Luis. n.d. Seasonal Agricutural Workers Program Mexico-Canada: Costs and Benefits. Washington DC: George Washington University.

Orkin, Aaron, Moran Lay, Janet McLaughlin., Michael Schwandt, and Donald Cole. Forthcoming. "Medical Repatriation of Migrant Farm Workers in Ontario: Coding and Descriptive Analysis." Canadian Medical Association Journal.

Nyberg-Sørensen, Ninna, Nicholas Van Hear and Paul Engberg-Pedersen (2002) The Migration-Development Nexus Toronto: International Organization for Migration.

Pantaleon, Jorge. 2011. “Mise en valeur, conversions et reconversions monetaires: les cycles des travailleurs agricoles saisonniers etrangers au Quebec". Alterites 8(1): 89-101.

Preibisch, Kerry and Jenna Hennebry. 2012. “Buy Local, Hire Global: Temporary Migration in Canadian Agriculture". Pp. 48-72 in Legislated Inequality: Temporary Labour Migration in Canada, edited by Patti Lennard and Christine Straehle. Kingston: Queen's University Press,.

Russell, Roy. 2003. “Jamaican Workers' Participation in CSAWP and 
Development Consequences in the Workers' Rural Communities". Canadian Migrant Agricultural Workers' Program Research Project. Ottawa: North-South Institute.

Satzewich, Vic. 1991. Racism and the Incorporation of Foreign Labour: Farm Labour Migration to Canada Since 1945. London: Routledge.

Sharma, Nandita. 2006. Home Economics: Nationalism and the Making of 'Migrant Workers' in Canada. Toronto: University of Toronto Press.

STyPS. n.d. a. "Dirección de Movilidad Laboral de la Secretaria del Trabajo y Previsión Social, Programa de Trabajadores Agricolas Temporales Mexico-Canada". Remesas 2010-2012 Mexico City: Mexico.

--------. n.d. b. “Dirección de Movilidad Laboral de la Secretaria del Trabajo y Previsión Social, Estadisticas y Mejoras PTAT 2007-2010". Internal Report of the General Coordination of National Employment Service Mexico City: Mexico.

Verduzco, Gustavo and Maria Lozano. 2003. “Mexican Farm Workers' Participation in Canada's Seasonal Agricultural Labour Market and Development Consequences in Their Rural Home Communities". NorthSouth Institute Research Project on Canada's Seasonal Agricultural Workers Program. Ottawa.

Wise, Timothy. 2010. "Agricultural Dumping Under NAFTA Report 7". Washington DC: Woodrow Wilson International Centre for Scholars.

World Bank. 2013. "Migration and Development Brief 21". Washington: World Bank. 